\title{
Впечатление психолога о проблемах беслана
}

Своеобразие психологических проблем первичных и вторичных жертв теракта в Беслане состоит в сочетании их индивидуальных психологических проблем с деструкиией межличностных отношений в республике, в том числе национальных, вероисповедальных, семейных и педагогических, а также - $c$ резким падением авторитета данных социальных институтов, в выраженном национальном колорите происходящих в республике перемен.

Причины этих явлений лежат в явной недооценке названных обстоятельств, неординарности происшедшей беды, сложившейся соииальной ситуации в Беслане и Северной Осетии в иелом представителями всех ветвей власти, органов правопорядка, системы образования и здравоохранения до, во время и после террористического акта; в имеющих место упущениях в ведении следствия, освещении его предварительных результатов, в распределении материальной помощи потерпевщим; в явном недоучете иенностей морального плана, начиональных, вероисповедальных, семейных традиций народа со славной историей; в бессистемном, случайном, непоследовательном характере профессиональной психологической помощи населению.

Ключевые слова: своеобразие психологических проблем жертв теракта в Беслане; трудности, непосредственно связанные с терактом; симптомь вторичного плана, усугубленные или спровочированные бесланской бедой; деструкиия самооценки и пищевого поведения жертв; стокгольмский синдром; психологические новообразования у жертв теракта; потребность в систематизащии профессиональной психологической помощи в Беслане.

Каждого из нас каким-то образом задела бесланская беда. Вплотную я занималась жертвами теракта трижды. В составе группы психологов Центра толерантности ЮФО при РГУ 4-6 октября 2004 года я была во Владикавказе и Беслане, а затем по приглашению Общероссийского союза общественных объединений «Гражданское общество - детям России» (Куратор проекта - председатель комиссии по правам человека при Президенте РФ, председатель Союза Э.А. Памфилова) 28 октября - 1 ноября участвовала в создании программы реабилитации жертв теракта и с 14 ноября по 5 декабря 2004 года осуществляла психологическую реабилитацию 
бывших заложников в санатории «Родник» в Пятигорске. Сейчас я поддерживаю связи со своими клиентами и коллегами в Беслане и Владикавказе.

Формы работы в октябре: лекции психологам средних школ и Центра медико-психолого-педагогической помощи «Доверие», которые дежурили возле бесланского Дворца культуры и оказывали помощь детям в Республиканской детской больнице; разбор реальных случаев из практики слушателей; анализ содержания надписей в здании СШ № 1 Беслана и публикаций российских газет о террористическом акте, в том числе газет Северной Осетии; групповые и индивидуальные консультации слушателям по поводу их профессиональных, личных и семейных проблем, связанных с событиями 1-3 сентября в Беслане. В качестве методической помощи - оставила психологам Владикавказа и Беслана пособия и статьи по актуальным проблемам психологической помощи.

В реабилитационной программе в Пятигорске участвовали жертвы теракта (22 ребенка от 2-х до 18-ти лет и 11 взрослых), а также - 72 их родственника, друзей и пр. Реабилитируемые в полном объеме получили комплексное санаторно-курортное лечение и психологическую помощь. В санатории работу осуществляли 10 специалистов: 5 начинающих социальных работников и психологов Владикавказа и 5 достаточно квалифицированных специалистов из Ставрополя, Ростова, Краснодара.

Мне пришлось непосредственно работать со следующими категориями клиентов: 1) детьми от 7-ми до 17-ти лет: 16 бывших заложников и 9 детей - родственники и друзья жертв; 2) взрослыми от 23-х до 72-х лет: 7 бывших заложников, в том числе 3 педагога СШ 1 и $15-$ близкие заложников.

Более чем у $60 \%$ заложников были зафиксированы физические травмы: минно-взрывные, осколочные и пулевые ранения, ожоги, сотрясение мозга и прочие. В 48\% случаев это были сочетанные травмы.

Формы работы в санатории: индивидуальная и групповая, в том числе семейная. В начале и в конце реабилитации осуществлялась психодиагностика; в течение всего времени использовались стратегии психологического консультирования и коррекции. В моих групповых занятиях участвовали от 2-х до 9-ти человек: 2 группы детей по 5 и 4 человека, группа педагогов школы, 3 супружеские пары и 7 семей, в каждой из которых было от 2 до 7 человек.

Основные психологические проблемы клиентов можно классифицировать на индивидуальные, семейные и групповые, а также условно разделить их на три группы: 1) Трудности, 
непосредственно связанные с терактом; 2) Симптомы вторичного плана, усугубленные или спровоцированные бесланской бедой; 3) Проблемы, инициированные или поддерживаемые значительными ошибками в организации помощи жертвам, в том числе и их профессиональной психологической реабилитации.

В данной статье кратко остановлюсь лишь на первых двух группах трудностей: 1) на устойчивых индивидуальных и групповых психологических проблемах жертв теракта, которые вписываются в симптомокомплекс PTSR, и 2) на симптомах деструкции системы взаимоотношений в Беслане, в республике.

Из PTSR-симптомов представлю те два, что, на мой взгляд, не описань в спецуиальной литературе (деструкцию самооценки и пищевого поведения жертв), несомненно, известный Стокгольмский симптом, которому, полагаю, бесланские события добавили информативности, а также - фиксированные у жертв известные психологические новообразования/ Бассин Ф.В., Рожнов В.Е., Рожнова М.А., 1979; Василюк Ф.Е., 1990; Б.Колодзин, 1992; М.Ш.Магомед-Эминов, 1998; И.В.Соловьев, 2000; Н.В.Тарабрина, 2001; Н.В.Тарабрина, Е.О.Лазебная, 1992; А.И.Тащёва, 1992, 2001; Е.М.Черепанова, 1995, 1996 и др./.

Деструкция самооценки у детей и взросльх. У абсолютного большинства первичных жертв теракта (собственно заложники) зафиксирована неадекватно низкая самооценка, а у вторичных жертв (близкие и друзья заложников) - самооценка значительно заниженная или завышенная.

До $81,2 \%$ всех опрошенных констатируют существенную динамику самооценки, напрямую связывая её с событиями 1-3 сентября. При этом согласно ретроспективным отчетам клиентов, самооценка которых имела явную динамику в результате теракта, негативная трансформация самооценки среди первичных жертв имела место у 90,2\% взрослых и у 100\% детей; показатели самооценки вторичных жертв были несколько иными: у 96,4\% взрослых и у 77,3\% детей. Позитивное преобразование самооценки зафиксировано, соответственно, лишь у 1 взрослого заложника; у родственников и ближайших друзей заложников - 3,6\% у взрослых и $22,7 \%$ - у детей.

Значительные нарушения пищевого поведения первичных $u$ вторичных жертв теракта. И через 1,5 месяца после теракта люди отказывались есть традиционные для осетин и прежде любимые ими мясные блюда, особенно жареные и копченые, так как «от них исходил запах копченых человеческих тел»; категорически отвергали пюре любого происхождения: это блюдо напоминало «размазанные по потолку, стенам, полу останки тел убитых», на которые многие из 
спасшихся жертв были вынуждены наступать, «подчиняясь командам бандитов, а затем и спецназовцев, либо по собственной воле, так как понимали, что иначе им не выбраться из этого ада».

Абсолютное большинство жертв чувствовали себя лучше, спокойнее, комфортнее, если видели рядом доступные для них источники воды. Многие дети и взрослые стали пить непривычно много жидкости, выпивая, например, в течение ночи до 1-3 литров воды, хотя физиологические параметры внутренней среды их организмов оказались не измененными. До сих пор многие матери Беслана при первой же просьбе ребенка подают ему не привычную чашку с водой, а непременно литровую-полуторолитровую бутылку воды и т.д. «Пищевые и водные мотивы» и сегодня оказываются типичными сюжетами тревожных, болезненных сновидений, рисунков, размышлений и «цветущих», полиморфных страхов потерпевших, их ярких воспоминаний.

Во время теракта 87,3\% опрошенных взрослых, находившиеся вне школы, отказывали себе в праве принимать пищу и 22,7\% отказывались пить: «Поем-попью вместе с сыном-дочерью»...

Стокгольмский и пр. симптомы как следствия насильственного удержания. Признаки Стокгольмского синдрома зафиксированы у 54,5\% взрослых заложников и 18,2\% детей. Эти люди, достаточно точно описывая кошмары 52-х часов заточения в школе и свои тяжкие переживания, говорили, что с ужасом ожидали от террористов ещё большей агрессии, чем та, что они проявили. Выявилось, что 86,7\% этих реабилитируемых до и после событий в школе неоднократно подвергались различным видам насилия: 6 человек - физическому, 2 человека - сексуальному, 10 психологическому и 4 человека - экономическому. Формы насилия обычно сочетались. При этом 8 детей и 5 взрослых воспроизводили примеры «человеческого» поведения террористов: «сказал намочить белье под одеждой, а потом его сосать вместо воды», «вывел на ночь пожилых женщин из спортзала в другое помещение, где можно было полежать на полу, впервые за двое суток вытянув ноги», бросил шоколадку. Один ребенок рассказывал, что террорист спас его во время штурма, приказав лечь за тела убитых и прикрыв его своей курткой.

Из диагностированных психологических новообразований $у$ жертв теракта упомяну лишь самые типичные, суть которых метафорически может быть сформулирована следующим образом:

«Я был там, а вы (они) не были, следовательно, не поймете и не имеете права сейчас меня судить»...

«Государство должно компенсировать»...

«Синдром ограничения свободы». 
«Вина выживших».

«Все они (чеченцы, ингуши, осетины, русские) доброго слова не стоят»...

«Всегда быть начеку».

«Куда мне деться от этих воспоминаний?»

Гнев по отношению к себе («Я мог поступить тогда иначе!»), к другим («Где все они были?» и «Где они сейчас, когда мне так плохо?»).

Деструктивное самовосприятие в условиях насильственного удержания и после них: в вариантах ущербности («Тогда и сейчас я никчемен, слаб, труслив, недостоин»...) или омнипотенции (явное переоценивание собственных реальных возможностей в травматических обстоятельствах).

«Я боюсь, что все это может повториться»...

Наконец, - о симптомах вторичного плана, усугубленных или спровочированных бесланской бедой. До сентября 2004 года эти проблемы были актуальными лишь для определенных групп граждан, а какие-то из них казались невозможными по определению.

Самые типичные из этих симптомов следующие: публичный нигилизм подростков старшего и среднего возраста, юношей по отношению $\kappa$ некоторым национальным традициям общения $c$ посторонними людьми; очевидное и не скрываемое пренебрежение детей от 7 лет к родителям, старшим сиблингам (братьям и сестрам) и другим близким, беспрецедентно резкое падение авторитета власти республики Северная Осетия, авторитета силовых структур, системы образования и здравоохранения; снижение авторитета педагогов средних школ республики.

Например, юноши и подростки стали демонстративно игнорировать традици обязательного подчеркнуто уважительного отношения к старшим, в том числе и к лицам мужского пола: подросток продолжает сидеть, не встает, когда к нему обращается взрослый мужчина; развалившись, сидит за праздничным столом, когда мужчина произносит тост, а другие мужчины из уважения к говорящему почтительно стоят; наконец, подросток открыто сквернословит в присутствии старших и пр.

C особым трагизмом взрослье осетины воспринимают поведение детей, которое нарушает незыблемые прежде традиции семейных отношений. До 1 сентября 2004 года взаимоотношения во многих патриархальных осетинских семьях (а их в республике было большинство) строились в соответствии со строгими традициями поведения поло-ролевого, поколенческого и с учетом порядка рождения ребенка. 
Так, младший ребенок в осетинской семье - самый любимый, именно он сотни лет до конца дней своих оставался объектом самой пристальной заботы всех членов расширенной семьи. Но именно он по самому факту рождения последним в семье всегда был обязан ухаживать за всеми старшими в доме, безоговорочно принимать поручения от любого члена семьи, старше его даже на несколько месяцев. Спасти младшего дитя от данной участи могли лишь два события: рождение еще одного ребенка или появление в доме невестки, чей статус в данной семье априорно оказывался минимальным. Возраст невестки не имел при этом значения. Ей мог давать поручения и младший ребенок, как только он в принципе научался это делать.

После сентябрьских событий дети-заложники, а вслед за ними и другие дети Беслана стали пытаться самостоятельно усаживаться на неприкосновенное место отца за столом, стали активно отказываться от выполнения своих привычных домашних обязанностей, открыто игнорировать поручения родителей, старших братьев и сестер, других близких. Сами дети признают, что они стали значительно больше грубить, лгать родителям и старшим сиблингам. У некоторых из них впервые в жизни пробудилась потребность вслух возражать отцу и, более того, вопреки традициям, в том числе и традициям физических наказаний, они стали отстаивать перед отцом собственные интересы, интересы братьев, сестер, матери.

Судя по нашим наблюдениям, выраженность данного симптома напрямую определяется возрастом детей, их личностными особенностями, наличием-отсутствием физической травмы во время теракта, ее тяжестью, а также поведением ребенка в ситуации заложничества, после освобождения и пр.

На мой взгляд, уникальность психологических трудностей жертв теракта в Беслане состоит в сочетании их индивидуальных психологических проблем с деструкцией традиционной системы межличностных отношений в республике, в том числе национальных, вероисповедальных, семейных и педагогических, с беспрецедентно резким падением авторитета данных социальных институтов, имеет выраженный национальный колорит. Ситуация, конечно же, осложняется цинизмом и кощунством организаторов и исполнителей теракта; очень большим числом погибших (330 человек, среди них 186 детей) и потерпевших (1343 человека); осознанной детьми беспомощности всегда действительно любящих, заботливых родителей и педагогов, бессилия взрослых в целом, наконец, страны.

Если в ближайшее время ситуация не изменится принципиальным образом, то дальнейшее развитие событий в 
Беслане и республике может развиваться по следующему сценарию: рост числа суицидов и соматических заболеваний; хронификация физических и психологических симптомов; вспышки активной, неуправляемой агрессии в адрес правительства всех уровней, представителей отдельных национальностей, средств массовой информации, педагогов, родителей выживших детей и пр. Словом, придется констатировать, что бандиты достигли цели - породили условия для уничтожения осетин как нации и создали дополнительные условия для дестабилизации положения не только на Северном Кавказе, но в какой-то мере в стране в целом.

Работать с описанными выше и прочими социальными и психологическими трудностями должны представители властных структур, системы образования и здравоохранения Северной Осетии и России, профессиональные психологи, педагоги, в том числе и педагоги-заложники, этнографы, журналисты, деятели искусства, родители.

Следует «проинвентаризировать», а затем ответственно и квалифицированно определить принципы и задачи работы местных и приезжих психологов в Беслане, контингент их клиентов, оптимальные методы и формы работы; объективно отслеживать динамику психологического здоровья жителей, в первую очередь первичных и вторичных жертв теракта; договориться о взаимодействии психологов и других специалистов в городе.

Потребность в систематизации, объединении усилий различных специалистов растет в связи с приближающимся судебным процессом над Н. Кулаевым; типичным этапом усиления посттравматической симптоматики (6-9 месяцев) и необходимостью серьезной, системной, в том числе и психологической подготовки республики, специалистов к 1 сентября 2005 года.

\section{Литература}

1. Бассин Ф.В., Рожнов В.Е., Рожнова М.А. Психическая травма. Руководство по психотерапии. - Ташкент: Медицина, 1979.

2. Василюк Ф.Е. Психология переживания. Анализ преодоления критических ситуаций.- М.: МГУ, 1990.

3. Колодзин Б. Как жить после психической травмы. Пер. Савельевой И.В.- Зеленоград: "Шанс", 1992.

4. Магомед-Эминов М.Ш. Трансформация личности. - М.: Психоаналитическая Ассоциация, 1998.

5. Соловьев И.В. Посттравматический стрессовый синдром: причины, условия, последствия. Оказание психологической помощи и психореабилитация.- М.: ООО "Август-БОРГ", 2000. 
6. Тарабрина Н.В. Практикум по психологии посттравматического стресса. - СПб., М., Харьков, Минск: ПИТЕР, 2001.

7. Тарабрина Н.В., Лазебная Е.О. Синдром посттравматических стрессовых нарушений. Современное состояние и проблемы.//Психологический журнал, 1992.т. 13, № 2.

8. Тащёва А.И. Своеобразие психологических проблем у жертв бесланского теракта./ Психология и педагогика социального воспитания. Материалы научно-практической конференции. Кострома: КГУ, 2005.

9. Тащёва А.И.Психологическая помощь лицам, потерявшим близких в результате катастроф. /Психология травматического стресса сегодня. Тезисы докладов международной конференции. - Киев: Общество "Знание", 1992.

10. Черепанова Е.М. Психологический стресс. Книга для школьных психологов, родителей и учителей. М.; Издательский центр "Шанс",1996.

11. Черепанова E.M. Саморегуляция и самопомощь при работе в экстремальных условиях. Руководство для спасателей и другого персонала служб быстрого реагирования. М.: Изд-во РГПУ, 1995. 